\title{
Effects of antibiotics on the growth and morphology of Pasteurella multocida
}

\author{
Mario JacQues, ${ }^{1 *}$ AnNie Lebrun, ${ }^{1}$ Bernadette Foiry,${ }^{1}$ Michèle Dargis ${ }^{2}$ and \\ FRANÇOIS MALOUIN ${ }^{2}$ \\ ${ }^{1}$ Groupe de Recherche sur les Maladies Infectieuses du Porc, Faculté de Médecine Vétérinaire, Université de Montréal, \\ CP 5000, St-Hyacinthe, Québec J2S 7C6, Canada \\ ${ }^{2}$ Laboratoire et Service d'Infectiologie, Centre de Recherche du Centre Hospitalier de l'Université Laval, Ste-Foy, \\ Québec G1V 4G2, Canada
}

(Received 3 April 1991; revised 1 July 1991; accepted 19 July 1991)

\begin{abstract}
The effects of subminimal inhibitory concentrations (subMICs) of certain antibiotics, namely penicillin G, tetracycline and trimethoprim/sulphamethoxazole, on the growth and morphology of Pasteurella multocida were evaluated. SubMICs of penicillin markedly reduced the growth of $P$. multocida. Tetracycline and trimethoprim/ sulphamethoxazole had no effect on its growth. SubMICs of penicillin greatly affected the morphology of $\boldsymbol{P}$. multocida. At the highest concentrations tested (1/2 and 1/4 MIC) cells were acapsulate, and long filamentous cells (4-6 $\mu \mathrm{m})$ were observed with some isolates. There was no correlation between the observed differences in the penicillin-binding proteins of the $\boldsymbol{P}$. multocida isolates, and the extent of cell filamentation induced by penicillin $G$. SubMICs of tetracycline and trimethoprim/sulphamethoxazole did not seem to affect capsule production although filamentation was observed. Our results indicate that subMICs of penicillin can reduce growth of $P$. multocida. Furthermore, results also indicate that subMICs of antibiotics can affect the production of capsular material and the morphology of $\boldsymbol{P}$. multocida.
\end{abstract}

\section{Introduction}

Porcine atrophic rhinitis is characterized by severe necrosis of the epithelia of the upper respiratory tract and by deformity and reduction both in volume and in size of the nasal turbinates and snout (Chanter \& Rutter, 1989; Rutter, 1985). Atrophic rhinitis is a multifactorial disease complex. It is generally agreed that Bordetella bronchiseptica and Pasteurella multocida are capable of causing atrophy of nasal turbinates in pigs, but the severity and persistence of the changes they induce are different (Rutter, 1985). Infection with B. bronchiseptica permits colonization by $P$. multocida and leads to more severe lesions than does infection with either microorganism alone. Feed medication containing tetracyclines alone, or in combination with penicillin and sulphonamides, can reduce the clinical signs (Rutter, 1985). However, it is not clear if bactericidal drug concentrations are achieved on the mucosa of the upper respiratory tract of pigs.

Levels of antibiotics decrease with time following administration, and effective antibiotic concentrations may not be maintained long enough for optimal

Abbreviation: PBP, penicillin-binding protein. treatment. Additionally, the levels of antibiotics may not reach concentrations adequate to prevent multiplication of organisms in areas such as secretions in the nasal cavity or bronchial tree. For example, levels of penicillin $\mathrm{G}$ in nasal washings of rabbits at $4 \mathrm{~h}$ after intramuscular injection were $0.063 \mu \mathrm{g} \mathrm{ml}^{-1}$, or $1 / 4$ of the minimal inhibitory concentration (MIC) for $80 \%$ of the rabbit $P$. multocida isolates tested (Welch et al., 1987).

An increasing number of reports indicate that antibiotics can affect bacteria in ways other than the expected bactericidal or bacteriostatic action. Some of these effects are morphological changes (Atkinson \& Amaral, 1982; Chopra \& Linton, 1986; Lorian, 1980; Lorian \& Ernst, 1987), reduction of growth (Atkinson \& Amaral, 1982; Washington, 1979), inhibition of enzyme or toxin production (Shibl, 1983), loss of adhesive properties (Schifferli \& Beachey, 1988a,b; Shibl, 1985), and susceptibility to host humoral and cellular defences (Chopra \& Linton, 1986). These effects are usually observed when bacteria are incubated with antibiotics at levels below the MIC or subminimal inhibitory concentrations (subMICs).

In the absence of the bactericidal or bacteriostatic action of an antibiotic, other effects, which may help 
Table 1. MICs and capsular types of the five P. multocida isolates used in the present study

\begin{tabular}{lcccc}
\hline & & \multicolumn{3}{c}{ MIC $\left(\mu \mathrm{ml}^{-1}\right)^{*}$} \\
\cline { 3 - 5 } Isolate & $\begin{array}{c}\text { Capsular } \\
\text { type }\end{array}$ & Penicillin G & $\begin{array}{c}\text { Tetra- } \\
\text { cycline }\end{array}$ & $\begin{array}{c}\text { Trimethoprim/ } \\
\text { sulphamethoxazole }\end{array}$ \\
\hline $2305-\mathrm{A}$ & $\mathrm{A}$ & 0.25 & 0.5 & $0.2: 1$ \\
$23-4$ & $\mathrm{~A}$ & 0.06 & 0.5 & $0.2: 1$ \\
1604 & $\mathrm{D}$ & 0.1 & 0.25 & $0.1: 0.5$ \\
1703 & $\mathrm{D}$ & 0.05 & 0.25 & $0.1: 0.5$ \\
$30-1$ & $\mathrm{D}$ & 0.125 & 0.25 & $0.1: 0.5$ \\
\hline
\end{tabular}

* The MIC was the lowest concentration of antibiotic that prevented visible growth (Atkinson \& Amaral, 1982).

eliminate the bacteria from the host, may occur during subMIC antibiotic treatment. To our knowledge, no studies have looked at the effects of low concentrations of antibiotics on the aetiological agents of atrophic rhinitis. Thus, the purpose of the present work was to evaluate the effect of subMICs of antibiotics commonly used in the swine industry, namely penicillin G, tetracycline and trimethoprim/sulphamethoxazole (Prescott \& Baggot, 1988; Rutter 1985), on the growth and the morphology of $P$. multocida.

\section{Methods}

Bacterial isolates and growth conditions. Five isolates of $P$. multocida (two of capsular type A and three of capsular type D) and two isolates of $B$. bronchiseptica, retrieved from the nasal cavities of pigs with atrophic rhinitis, were used in the present study. The MICs of the isolates for penicillin $G$, tetracycline and trimethoprim/sulphamethoxazole $(1: 5)$ were determined by the agar dilution method (Washington \& Sutter, 1980) (Table 1). Escherichia coli ATCC 25922 and Pseudomonas aeruginosa ATCC 27853 were used as controls. The antibiotics were obtained from Sigma. Bacterial isolates were grown on MuellerHinton agar plates containing subMICs (i.e. $1 / 2,1 / 4$ or $1 / 8$ ) of the antibiotics tested, for $18 \mathrm{~h}$ at $37^{\circ} \mathrm{C}$. Control media without antibiotics were always used in parallel.

Effects of antibiotics on growth. Mueller-Hinton broth (50 $\mathrm{ml}$ vols), with or without various concentrations of antibiotics was inoculated with $0.5 \mathrm{ml}$ of a bacterial suspension containing $10^{8}$ c.f.u. $\mathrm{ml}^{-1}$ and incubated at $37^{\circ} \mathrm{C}$ with agitation ( 100 r.p.m.). Growth was monitored both spectrophotometrically at $540 \mathrm{~nm}$ and by viable counts at $0,4,8$, 24,48 and $72 \mathrm{~h}$.

$\beta$-Lactamase detection. All of our isolates were screened for $\beta$ lactamase production using a nitrocefin test (Malouin \& Lamothe, 1987). The chromogenic cephalosporin nitrocefin was purchased from Oxoid.
Labelling of penicillin-binding proteins (PBPs). The procedure for binding radiolabelled penicillin to whole bacterial cells was as described previously (Malouin et al., 1990). PBPs were radiolabelled by a modification of the method of Spratt (1977), as described by Preston et al. (1990) using ${ }^{125} \mathrm{I}$-labelled penicillin $\mathrm{V}$ as the labelled $\beta$-lactam (Blaszczak \& Halligan, 1988). The $p$-(trimethylstannyl)penicillin V was kindly provided by Larry C. Blaszczak (Lilly Research Laboratories, Eli Lilly \& Co., Indianapolis, IN, USA), and was iodinated by using $\mathrm{Na}^{125}$ I from Amersham. Cells in phosphate-buffered saline (PBS; $0.01 \mathrm{M}, \mathrm{pH} 7.2$ ) were incubated with $20 \mu \mathrm{g}{ }^{125} \mathrm{I}$-labelled penicillin $\mathrm{V}$ [37.3 $\left.\mathrm{Ci} \mathrm{mmol}^{-1}\left(1.38 \mathrm{TBq} \mathrm{mmol}^{-1}\right)\right] \mathrm{ml}^{-1}$ for $30 \mathrm{~min}$ at room temperature. The labelled cells were washed and loaded for electrophoresis on discontinuous $0 \cdot 1 \% \mathrm{SDS} / 10 \%$ (w/v) polyacrylamide gels (Laemmli \& Favre, 1973). Dried gels were subjected to Kodak X-Omat film for autoradiography $(7-14 \mathrm{~d})$ at $-20^{\circ} \mathrm{C}$.

\section{Effects of antibiotics on morphology}

Thin sectioning. Control bacterial cells and cells exposed to subMICs of antibiotics were prepared for transmission electron microscopy following polycationic ferritin labelling or fixation with glutaraldehyde/lysine, two methods which allow good preservation of capsular material (Jacques et al., 1990; Jacques \& Graham, 1989).

(i) Polycationic ferritin labelling. Bacterial cells were fixed in cacodylate buffer $(0 \cdot 1 \mathrm{M}, \mathrm{pH} 7 \cdot 0)$ containing $5 \%(\mathrm{v} / \mathrm{v})$ glutaraldehyde for $2 \mathrm{~h}$ at $20^{\circ} \mathrm{C}$. Fixed bacteria were suspended in cacodylate buffer and allowed to react with the polycationic ferritin (Sigma), final concentration $1.0 \mathrm{mg} \mathrm{ml}^{-1}$, for $30 \mathrm{~min}$ at $20^{\circ} \mathrm{C}$ (Jacques \& Foiry, 1987). The reaction was slowed by 10 -fold dilution with buffer, and the organisms were centrifuged and washed three times in cacodylate buffer. Bacterial cells were then immobilized in $4 \%(\mathrm{w} / \mathrm{v})$ agar, washed five times in cacodylate buffer, and post-fixed with $2 \%(w / v)$ osmium tetroxide for $2 \mathrm{~h}$. Washings were repeated as above, and the samples dehydrated in a graded series of acetone washes. Samples were then washed twice in propylene oxide and embedded in Spurr's lowviscosity resin. Thin sections were post-stained with uranyl acetate and lead citrate and examined with an electron microscope (Philips 201) at an accelerating voltage of $60 \mathrm{kV}$.

(ii) Fixation with glutaraldehyde/lysine. For fixation in the presence of lysine, bacterial cells were suspended in freshly prepared fixative consisting of 1 vol. cacodylate buffer containing $5 \%$ glutaraldehyde and $0.15 \%(\mathrm{w} / \mathrm{v})$ ruthenium red and 1 vol. cacodylate buffer containing $100 \mathrm{~mm}$-lysine for $20 \mathrm{~min}$ at room temperature (Jacques \& Graham, 1989). Cells were sedimented by centrifugation, and the fixation was continued for an additional $100 \mathrm{~min}$ in a solution that contained $5 \%$ glutaraldehyde and $0.15 \%$ ruthenium red in cacodylate buffer. Bacterial cells were then immobilized in $4 \%$ agar and processed as mentioned above.

Negative staining. Dense bacterial suspensions prepared in PBS were examined after negative staining. A drop of each preparation was placed on a 200-mesh Formvar-coated electron microscope grid and blotted partially dry. A drop of $2 \%(\mathrm{w} / \mathrm{v})$ phosphotungstate $(\mathrm{pH} 7.0)$ was then applied to the grid. Grids were examined as described above.

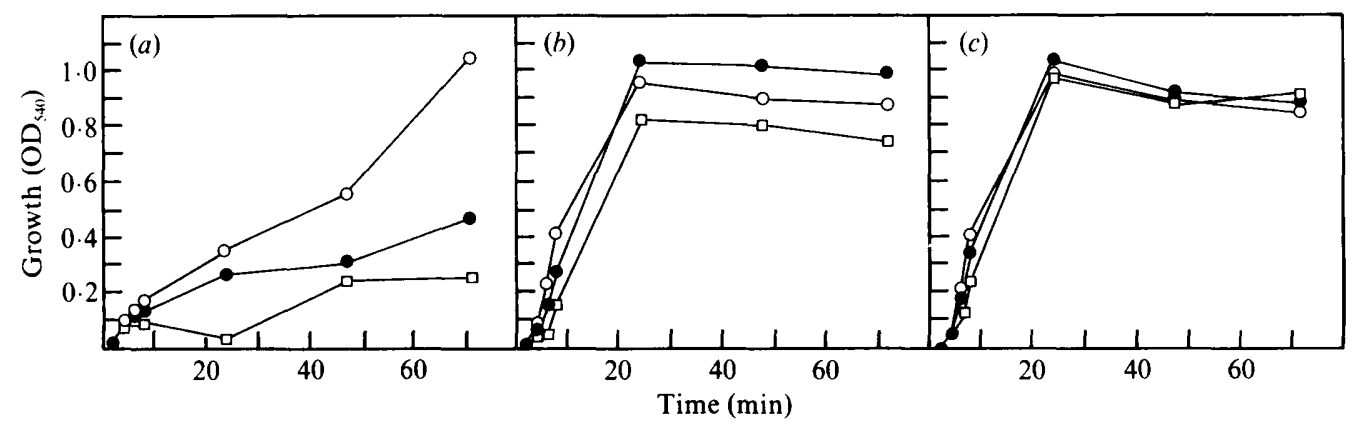

Fig. 1. Growth in liquid culture of a representative isolate of $P$. multocida (2305-A) in the presence of subMICs of penicillin G (a), tetracycline $(b)$ or trimethoprim/sulphamethoxazole $(c)$. Cultures: $O$, without antibiotic; $\square$, containing $1 / 2$ MIC;, containing $1 / 4$ MIC. 

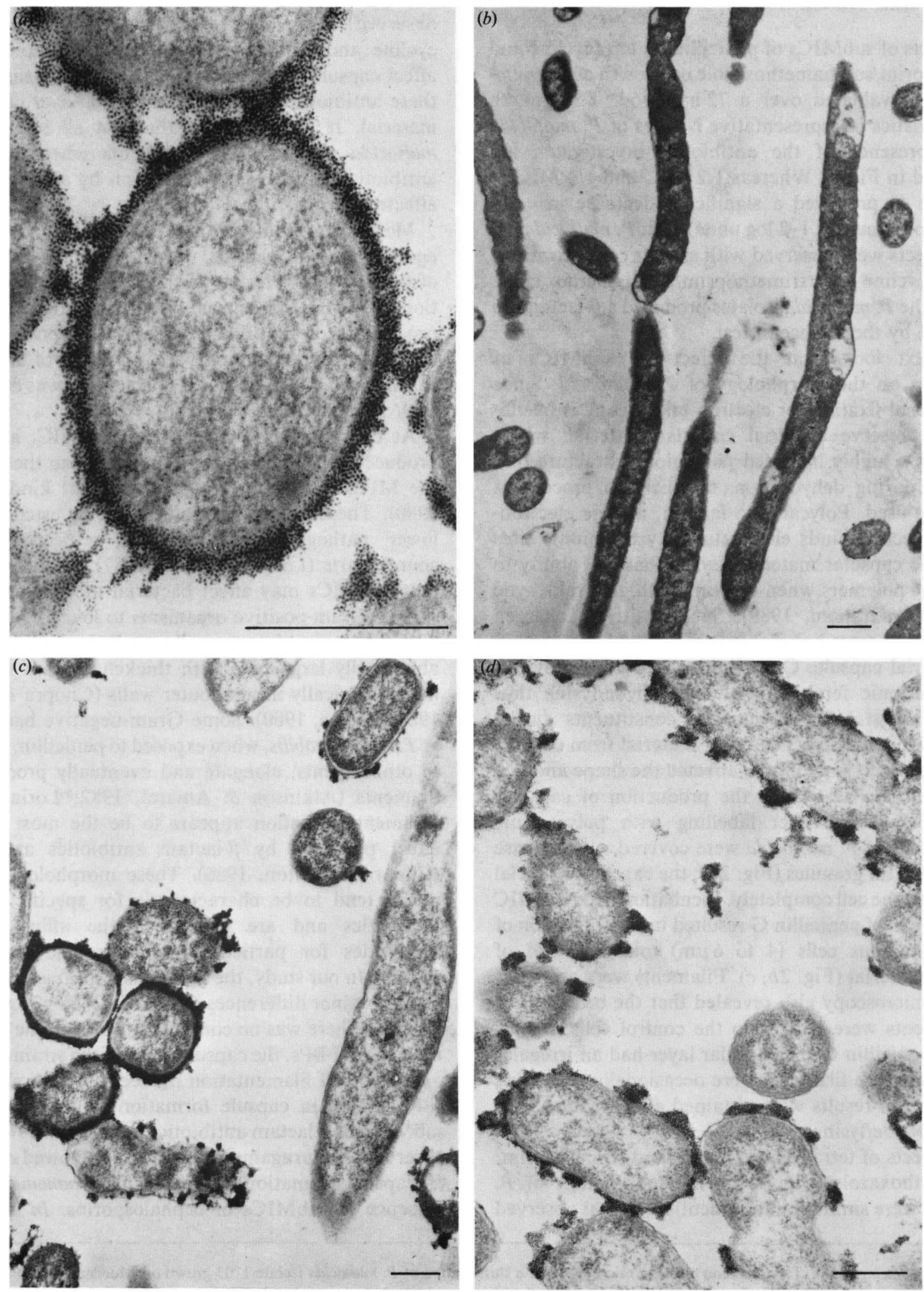

Fig. 2. Transmission electron micrographs of thin sections of $P$. multocida isolate 1703 grown on Mueller-Hinton agar plates. Cells were treated with polycationic ferritin. (a) Control, untreated cells. (b-d) Cells exposed to penicillin $\mathrm{G}(b, 1 / 2 \mathrm{MIC} ; c, 1 / 4 \mathrm{MIC} ; d, 1 / 8 \mathrm{MIC})$. Bars, $500 \mathrm{~nm}$. 


\section{Results and Discussion}

The effects of subMICs of penicillin G, tetracycline and trimethoprim/sulphamethoxazole on growth of $P$. multocida were evaluated over a $72 \mathrm{~h}$ period. The growth characteristics of representative isolates of $P$. multocida in the presence of the antibiotics investigated are illustrated in Fig. 1. Whereas $1 / 2 \mathrm{MIC}$ and $1 / 4 \mathrm{MIC}$ of penicillin $G$ produced a significant decrease in c.f.u. $\mathrm{ml}^{-1}$ (approximately 1-2 log units) with $P$. multocida, no major effects were observed with similar concentrations of tetracycline or trimethoprim/sulphamethoxazole. None of the $P$. multocida isolates produced a $\beta$-lactamase as judged by the nitrocefin test.

We next looked at the effects of subMICs of antibiotics on the morphology of $P$. multocida. Since conventional fixation for electron microscopy is insufficient to preserve bacterial capsular material, which comprises a highly hydrated polyanionic structure that collapses during dehydration, stabilization procedures had to be used. Polycationic ferritin, a large electrondense molecule, binds electrostatically to anionic sites within the capsular material. Lysine has the ability to form large polymers when reacting with glutaraldehyde (Jacques \& Graham, 1989). Such positively charged polymers can cross-link negatively charged sites within the bacterial capsule. Cross-linking activities provided by polycationic ferritin or glutaraldehyde/lysine thus enhance the stability of capsular constituents during dehydration and protect capsular material from collapsing. Exposure to penicillin $G$ affected the shape and size of $P$. multocida as well as the production of capsular material (Fig. 2). After labelling with polycationic ferritin, cells of $P$. multocida were covered with a dense layer of ferritin granules (Fig. 2a); the capsular material surrounded the cell completely. Incubation with $1 / 2$ MIC and $1 / 4 \mathrm{MIC}$ of penicillin $\mathrm{G}$ resulted in the formation of long filamentous cells $(4$ to $6 \mu \mathrm{m}$ ) totally devoid of capsular material (Fig. 2b,c). Filaments were aseptate; electron microscopy also revealed that the cell walls of the filaments were similar to the control cells. At $1 / 8$ MIC of penicillin $G$ the capsular layer had an irregular aspect and some filaments were occasionally seen (Fig. $2 d$ ). Identical results were obtained after fixation with glutaraldehyde/lysine.

The effects of tetracycline (Fig. 3) and trimethoprim/ sulphamethoxazole (Fig. 4) on the morphology of $P$. multocida were similar but not identical to that observed with penicillin G. Filamentous cells $(2-5 \mu \mathrm{m})$ were also observed; however, in contrast to penicillin $G$, tetracycline and trimethoprim/sulphamethoxazole did not affect capsule production. Cells exposed to subMICs of these antibiotics were covered with a layer of capsular material. It is noteworthy that not all isolates of $P$. multocida produced long filaments when exposed to antibiotics, but capsule production by all of them was affected by penicillin $\mathrm{G}$.

Morphology and growth of $B$. bronchiseptica, the other agent of atrophic rhinitis, were not affected by subMICs of the antibiotics tested, even at the highest concentration (1/2 MIC) (results not shown). Furthermore, the production of fimbriae by $B$. bronchiseptica was also unaffected by incubation with subMICs of antibiotics. In contrast to $P$. multocida, a $\beta$-lactamase was detected in both $B$. bronchiseptica isolates.

At concentrations lower than the MIC, antibiotics produce effects which are not milder than those seen at the MIC, but which are of a different kind (Lorian, 1980). These altered forms of bacteria usually exhibit lower pathogenicity than their respective normal counterparts (Lorian \& Ersnt, 1987). It is well known that subMICs may affect bacterial morphology. Exposure of Gram-positive organisms to low concentrations of $\beta$-lactam antibiotics usually results in the formation of abnormally large cells with thickened cross walls, but morphologically normal outer walls (Chopra \& Linton, 1986; Lorian, 1980). Some Gram-negative bacilli, such as Proteus mirabilis, when exposed to penicillin, as well as to other agents, elongate and eventually produce long filaments (Atkinson \& Amaral, 1982; Lorian, 1980). Filament formation appears to be the most common effect produced by $\beta$-lactam antibiotics at subMIC (Chopra \& Linton, 1986). These morphological alterations tend to be characteristic for specific $\beta$-lactam antibiotics and are related to the affinity of the antibiotics for particular penicillin-binding proteins (PBPs). In our study, the five $P$. multocida isolates tested showed minor differences in their PBP banding patterns (Fig. 5). There was no correlation between the observed changes in PBPs, the capsular type of the strains, and the extent of cell filamentation induced by penicillin $G$.

Reduction in capsule formation in the presence of subMICs of $\beta$-lactam antibiotics has not been frequently observed. Kadurugamuwa et al. (1985) showed reduction of capsule formation in Klebsiella pneumoniae in the presence of subMICs of cephalosporins. In vivo, such

Fig. 3 (facing page). Transmission electron micrograph of a thin section of $P$. multocida isolate 1703 grown on Mueller-Hinton agar plates containing 1/4 MIC of tetracycline. Cells were fixed with glutaraldehyde/lysine and stained with ruthenium red. Bar, 500 nm. Fig. 4 (facing page). Transmission electron micrograph of a thin section of $P$. multocida isolate 23-4 grown on Mueller-Hinton agar plates containing $1 / 4 \mathrm{MIC}$ of trimethoprim/sulphamethoxazole. Cells were fixed with glutaraldehyde/lysine and stained with ruthenium red. Bar, $500 \mathrm{~nm}$. 


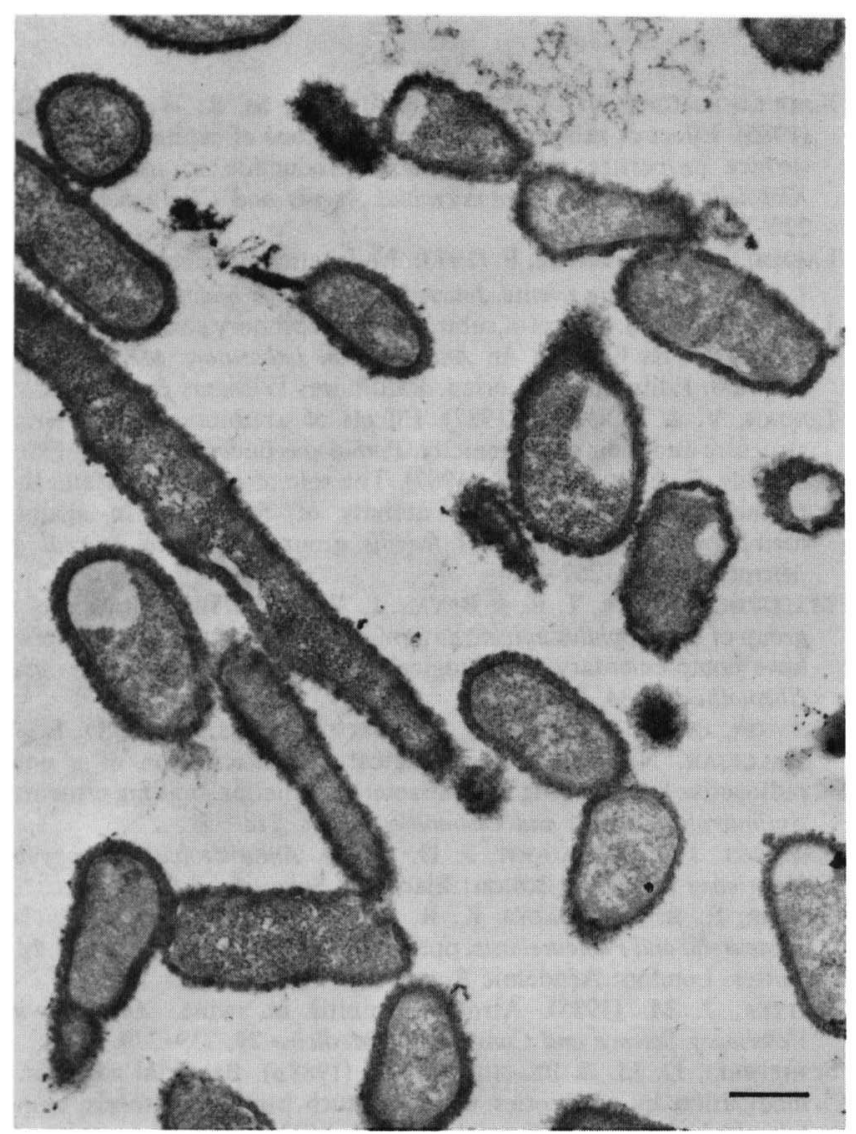

Fig. 3

(a)

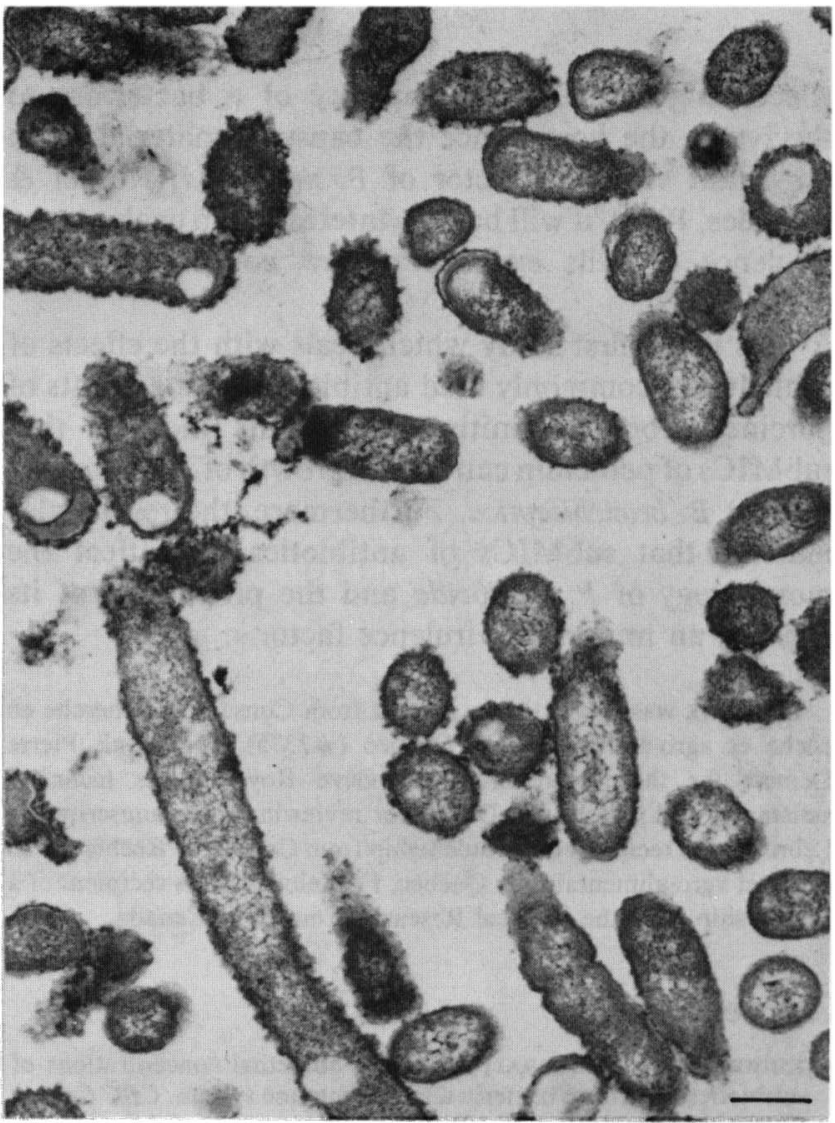

Fig. 4

(b)

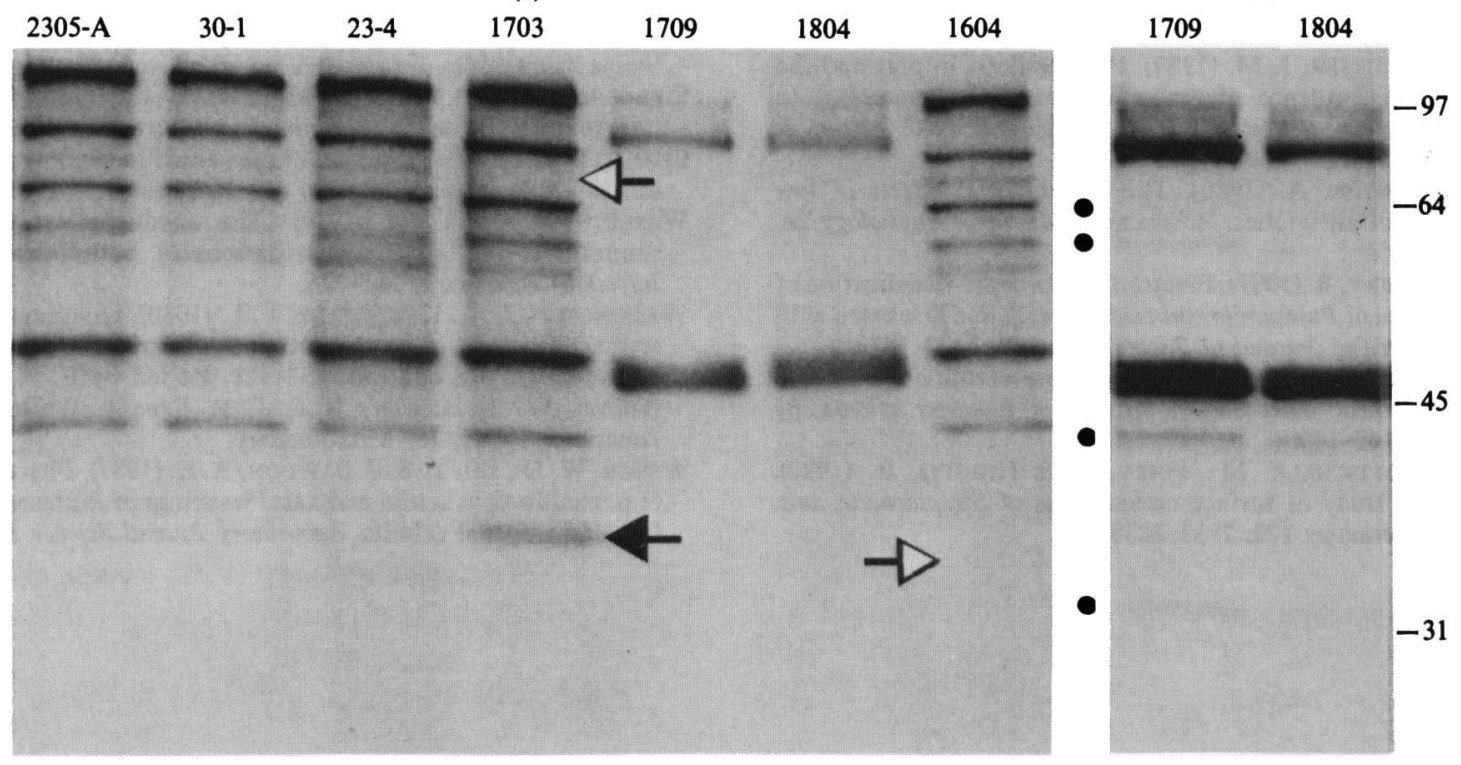

Fig. 5. Autoradiograph of $P$. multocida and B. bronchiseptica isolates labelled with ${ }^{125}$ I-labelled penicillin V. Strains: $P$. multocida capsular type A (2305-A and 23-4) and capsular type D (30-1, 1703 and 1604); B. bronchiseptica (1709 and 1804). Whole cells were labelled for $30 \mathrm{~min}$ with ${ }^{125} \mathrm{I}$-labelled penicillin V $\left(20 \mu \mathrm{g} \mathrm{ml}^{-1}\right)$ before electrophoresis on a SDS-polyacrylamide $(10 \%$, w/v) slab gel. For labelling of B. bronchiseptica, clavulanic acid (a gift from SmithKline Beecham Pharmaceuticals, Surrey, UK) at $0 \cdot 1 \mu \mathrm{g} \mathrm{m} \mathrm{l}^{-1}$ was also added to the reaction mixture to prevent hydrolysis of ${ }^{125} \mathrm{I}$-labelled penicillin $\mathrm{V}$ by $\beta$-lactamases. The PBP banding patterns were revealed by autoradiography for $7 \mathrm{~d}(a)$ or $14 \mathrm{~d}(b)$; molecular mass markers $(\mathrm{kDa})$ are indicated on the right. The black arrowhead indicates a PBP that is absent in the other strains of the same species, whereas the white arrowheads show the labelled proteins that are missing in the indicated strain.,$B$. bronchiseptica PBPs that showed low binding of ${ }^{125}$ I-labelling penicillin $\mathrm{V}$ and were revealed only after autoradiography for $14 \mathrm{~d}$. 
effects might reduce the capacity of a bacterium to survive in the host. Since the capsular material is an important virulence factor of $P$. multocida (Rimler \& Rhoades, 1989), it will be very interesting to evaluate the virulence of cells exposed to low concentrations of penicillin G.

This is the first study which deals with the effects of subMICs of commonly used antibiotics on the agents of porcine atrophic rhinitis. Our results indicate that subMICs of penicillin can reduce growth of $P$. multocida, but not $B$. bronchiseptica. Furthermore, the results also indicate that subMICs of antibiotics can affect the morphology of $P$. multocida and the production of its capsule, an important virulence factor.

This work was supported by a grant from Conseil de recherche en pêche et agro-alimentaire du Québec (\#2375). We thank Pierre Demers for the illustrations, Geneviève Roy for her technical assistance, and Charles M. Dozois for reviewing the manuscript. A. Lebrun is the recipient of a Studentship from Conseil de Recherche en pêche et agro-alimentaire du Québec. F. Malouin is the recipient of a Scholarship from the Medical Research Council of Canada.

\section{References}

Atxinson, B. A. \& Amaral, L. (1982). Sublethal concentrations of antibiotics, effects on bacteria and the immune system. CRC Critical Reviews in Microbiology 9, 101-138.

Blaszczak, L. C. \& Halligan, N. G. (1988). Radioiododestannylation. Convenient synthesis of a penicillin derivative for rapid penicillin binding protein (PBP) assay. Journal of Labelled Compounds and Radiopharmaceuticals 27, 401-406.

Chanter, N. \& Rutter, J. M. (1989). Pasteurellosis in pigs and the determinants of virulence of toxigenic Pasteurella multocida. In Pasteurella and Pasteurellosis, pp. 161-195. Edited by C. Adlam \& J. M. Rutter. London: Academic Press.

Chopra, I. \& Linton, A. (1986). The antibacterial effects of low concentrations of antibiotics. Advances in Microbial Physiology 28, 211-259.

JACQUES, M. \& FOIRY, B. (1987). Electron microscopic visualization of capsular material of Pasteurella multocida types A and D labeled with polycationic ferritin. Journal of Bacteriology 169, 3470-3472.

JACQUES, M. \& GRAHAM, L. (1989). Improved preservation of bacterial capsule for electron microscopy. Journal of Electron Microscopy Techniques 11, 167-169.

JacQues, M., GotTschalk, M., Foiry, B. \& Higgins, R. (1990). Ultrastructural study of surface components of Streptococcus suis. Journal of Bacteriology 172, 2833-2838.
Kadurugamuwa, J. L., Anwar, H. Brown, M. R. W. \& Zak, O. (1985). Effect of subinhibitory concentrations of cephalosporins on surface properties and siderophore production in iron-depleted Klebsiella pneumoniae. Antimicrobial Agents and Chemotherapy 27, 220-223.

LAEMMLI, U. K. \& FAVRE, F. (1973). Maturation of bacteriophage T4. I. DNA packaging events. Journal of Molecular Biology 80, 575-599.

LORIAN, V. (1980). Effects of subminimum inhibitory concentrations of antibiotics on bacteria. In Antibiotics in Laboratory Medicine, pp. 342-408. Edited by V. Lorian. Baltimore: Williams \& Wilkins.

LORIAN, V. \& ERNST, J. (1987). Effects of antibiotics on bacterial structure and their pathogenicity. Pathologie Biologie 35, 1370-1376.

Malouin, F. \& Lamothe, F. (1987). The role of $\beta$-lactamase and the permeability barrier on the activity of cephalosporin against members of the Bacteroides fragilis group. Canadian Journal of Microbiology 33, 262-266.

Malouin, F., PARR, T. R. \& BRyan, L. E. (1990). Identification of a group of Haemophilus influenzae penicillin-binding proteins that may have complementary physiological roles. Antimicrobial Agents and Chemotherapy 34, 363-365.

Preston, D. A., Wu, C. Y. E., Blaszczak, L. C., Seitz, D. E. \& HalligaN, N. G. (1990). Biological characterization of a new radioactive labeling reagent for bacterial penicillin-binding proteins. Antimicrobial Agents and Chemotherapy 34, 718-721.

Prescott, J. F. \& Baggot, J. D. (1988). Antimicrobial Therapy in Veterinary Medicine. Boston: Blackwell Scientific Publications.

Rimler, R. B. \& RHOADES, K. R. (1989). Pasteurella multocida. In Pasteurella and Pasteurellosis, pp. 37-73. Edited by C. Adlam \& J. M. Rutter. London: Academic Press.

RuTTER, J. M. (1985). Atrophic rhinitis in swine. Advances in Veterinary Science and Comparative Medicine 29, 239-279.

SCHIFFERLI, D. M. \& BeACHEY, E. H. (1988a). Bacterial adhesion: modulation by antibiotics which perturb protein synthesis. Antimicrobial Agents and Chemotherapy 32, 1603-1608.

SCHIFFERLI, D. M. \& BEACHEY, E. H. (1988b). Bacterial adhesion: modulation by antibiotics with primary targets other than protein synthesis. Antimicrobial Agents and Chemotherapy 32, 1609-1613.

SHIBL, A. M. (1983). Effect of antibiotics on production of enzymes and toxins by microorganisms. Reviews of Infectious Diseases 5, 865-875,

SHIBL, A. M. (1985). Effect of antibiotics on adherence of microorganisms to epithelial cell surfaces. Reviews of Infectious Diseases 7, 51-65.

SPRATT, B. G. (1977). Properties of the penicillin-binding proteins of $E$. coli K-12. European Journal of Biochemistry 72, 341-352.

WASHINGton, J. A., II (1979). The effects and significance of subminimal inhibitory concentrations of antibiotics. Reviews of Infectious Diseases 1, 781-786.

WAShington, J. A., II \& SUTTER, V. L. (1980). Dilution susceptibility test : agar and macro-broth dilution procedures. In Manual of Clinical Microbiology, 3rd edn, pp. 453-458. Edited by E. H. Lenette, A. Balows, W. J. Hausler, Jr \& J. P. Truant. Washington, DC: American Society for Microbiology.

WeLCH, W. D., Lu, Y.-S. \& BAWDON, R. E. (1987). Pharmacokinetics of penicillin-G in serum and nasal washings of Pasteurella multocida free and infected rabbits. Laboratory Animal Science 37, 65-68. 